\title{
Diketopiperazine and Diphenylether Derivatives from Marine Algae-Derived Aspergillus versicolor OUCMDZ-2738 by Epigenetic Activation
}

\author{
Wen Liu ${ }^{1,2,+}$, Liping Wang ${ }^{2,+}$, Bin Wang ${ }^{1}$, Yanchao $\mathrm{Xu}^{2}{ }^{2}$, Guoliang $\mathrm{Zhu}^{3,4}{ }^{\text {, Mengmeng Lan }}{ }^{3}$, \\ Weiming Zhu $2,3,5, *$ and Kunlai Sun $1, * \mathbb{D}$ \\ 1 Zhejiang Provincial Engineering Technology Research Center of Marine Biomedical Products, School of \\ Food and Pharmacy, School of Marine Science and Technology, Zhejiang Ocean University, Zhoushan \\ 316022, China; yxlliuwen@outlook.com (W.L.); wangbin4159@hotmail.com (B.W.) \\ 2 State Key Laboratory of Functions and Applications of Medicinal Plants, Guizhou Medical University, \\ Guiyang 550014, China; lipingw2006@163.com (L.W.); m18586818694@163.com (Y.X.) \\ 3 Key Laboratory of Marine Drugs, Ministry of Education of China, School of Medicine and Pharmacy, \\ Ocean University of China, Qingdao 266003, China; zhuguoliang@ecust.edu.cn (G.Z.); \\ lanmengmeng90@163.com (M.L.) \\ 4 State Key Laboratory of Bioreactor Engineering, East China University of Science and Technology, Shanghai \\ 200237, China \\ 5 Open Studio for Druggability Research of Marine Natural Products, Pilot National Laboratory for Marine \\ Science and Technology (Qingdao), Qingdao, 266237, China \\ * Correspondence: weimingzhu@ouc.edu.cn (W.Z.); sunqinlai@126.com (K.S.); Tel./Fax: +86-532-8203-1268 \\ (W.Z.); +86-580-255-4781 (K.S.) \\ + These authors contributed equally to this paper.
}

Received: 28 November 2018; Accepted: 20 December 2018; Published: 22 December 2018

check for updates

\begin{abstract}
A chemical-epigenetic method was used to enhance the chemodiversity of a marine algicolous fungus. Apart from thirteen known compounds, (+)-brevianamide $R((+)-3)$, (-)-brevianamide R ((-)-3), (+)-brevianamide Q ((+)-4), (-)-brevianamide Q ((-)-4), brevianamide V ((+)-5), brevianamide W ((-)-5), brevianamide K (6), diorcinol B (7), diorcinol C (8), diorcinol E (9), diorcinol J (10), diorcinol (11), 4-methoxycarbonyldiorcinol (12), two new compounds, (+)- and (-)-brevianamide $X((+)-$ and (-)- 2)), as well as a new naturally occurring one, 3-[6-(2-methylpropyl)-2-oxo-1H-pyrazin-3-yl]propanamide (1), were isolated from chemical-epigenetic cultures of Aspergillus versicolor OUCMDZ-2738 with $10 \mu \mathrm{M}$ vorinostat (SAHA). Compared to cultures in the same medium without SAHA, compounds $\mathbf{1 - 4}, \mathbf{8}, \mathbf{9}, \mathbf{1 1}$, and 12 were solely observed under SAHA condition. The structures of these compounds were elucidated based on spectroscopic analysis, specific rotation analysis, ECD, and X-ray crystallographic analysis. ( \pm )-3, $( \pm)-4$, and $( \pm)-5$ were further resolved into the corresponding optically pure enantiomers and their absolute configurations were determined for the first time. Compounds $\mathbf{1 1}$ and $\mathbf{1 2}$ showed selective antibacterial against Pseudomonas aeruginosa with a minimum inhibitory concentration (MIC) of 17.4 and $13.9 \mu \mathrm{M}$, respectively. Compound $\mathbf{1 0}$ exhibited better $\alpha$-glucosidase inhibitory activity than the assay control acarbose with $\mathrm{IC}_{50}$ values of 117.3 and $255.3 \mu \mathrm{M}$, respectively.
\end{abstract}

Keywords: chemical-epigenetic method; endophytic fungus; Aspergillus versicolor; enantiomer; antimicrobial activity

\section{Introduction}

Marine natural products (NPs) are an important source for developing new drugs, especially those from marine-derived fungi which possess novel structures and significant biological activities $[1,2]$. 
Aspergillus is a kind of productive fungal genus and has been reported to produce many new NPs [3], such as alkaloids [4-6], diketopiperazines [7,8], xanthones [8], and diphenyl ethers [9]. However, the whole genome sequencing studies of fungi have indicated that most genes of fungi were silent and not expressed in the conventional experimental conditions. Fungi treated with DNA methyltransferase and histone deacetylase inhibitors enhanced NPs' chemical diversity, demonstrating that small molecule epigenetic modifiers are effective tools for rationally generating new and bioactive NPs [10]. Both molecular-based and chemical approaches targeting histone and DNA posttranslational processes have the great potential for rationally activating or suppressing NP-encoding gene clusters [11-13]. Epigenetic modification has become a widely applied strategy to find new and bioactive NPs today [14-16].

In our continuous study on the discovery of new and bioactive NPs from algicolous microorganisms isolated from Enteromorpha prolifera by epigenetic modification [12,13] and other strategies [17-19], we found that the algicolous Aspergillus versicolor OUCMDZ-2738 could produce different NPs after chemical-epigenetic modification by $10 \mu \mathrm{M}$ SAHA. From the epigenetically modified fermentation of A. versicolor OUCMDZ-2738, we isolated and identified a new naturally occurring compound 1, two new enantiomers ((+)-2 and (-)-2), and thirteen known compounds (3-12). Their structures were determined as 3-[6-(2-methylpropyl)-2-oxo-1H-pyrazin-3-yl] propanamide (1), (+)-brevianamide $X((+)-2)$ and (-)-brevianamide $X((-)-2),( \pm)$-brevianamide $R$ (3) [20], ( \pm )-brevianamide $\mathrm{Q}(4)$ [20], brevianamide $\mathrm{V}((+)-5)$ [21], brevianamide $\mathrm{W}((-)-5)$ [22], brevianamide K (6) [23], diorcinol B (7) [24], diorcinol C (8) [24], diorcinol E (9) [24], diorcinol J (10) [24], diorcinol (11) [25], and methyl diorcinol-4-carboxylate (12) [26,27], respectively (Figure 1). ( \pm )-Brevianamide $R$ (3) and ( \pm )-brevianamide $Q(4)$ were further resolved as (+)- and (-)- brevianamide $R((+)$ - and (-)- 3$)$ and (+)- and (-)- brevianamide $Q((+)-$ and (-)- 4), respectively.<smiles>[Y]C(C)Cc1cnc(CCC(N)=O)c(=O)[nH]1</smiles>

1

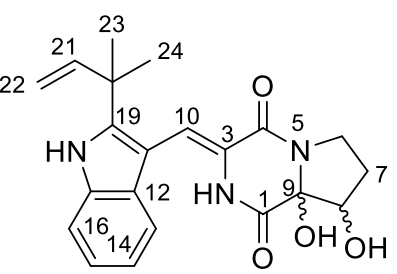

$(+)-2: 8 S, 9 S ;(-)-2: 8 R, 9 R$<smiles>[R]C12CCCN1C(=O)C(=Cc1c(C(C)(C)C=C)[nH]c3ccccc13)NC2=O</smiles><smiles>C=CC(C)(C)c1[nH]c2ccccc2c1/C=c1\[nH]c(=O)c2n(c1=O)CCC=2</smiles>

$(+)-3: \mathrm{R}=(9 R)-\mathrm{OMe} ;(-)-3: \mathrm{R}=(9 S)-\mathrm{OMe} \quad 6$

$(+)-4: \mathrm{R}=(9 R)-\mathrm{OH} ;(-)-4: \mathrm{R}=(9 S)-\mathrm{OH}$

$(+)-5: \mathrm{R}=(9 S)-\mathrm{H} ;(-)-5: \mathrm{R}=(9 R)-\mathrm{H}$<smiles>[R]c1c(C)cc(O)cc1Oc1cc(C)cc(O)c1</smiles>

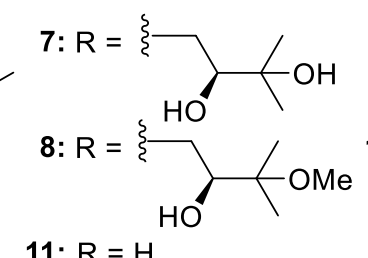

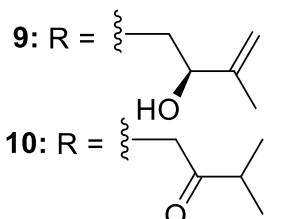

11: $\mathrm{R}=\mathrm{H}$<smiles>[R]OC(=O)c1c([R20])cc(Oc2cc(C)cc(O[R])c2)cc1C</smiles>

$12: R=H ; 12 a: R=M e$

Figure 1. Structures of compounds 1-12.

\section{Results and Discussion}

Compound 1 was isolated as a brown, amorphous powder. The molecular formula was determined as $\mathrm{C}_{11} \mathrm{H}_{17} \mathrm{O}_{2} \mathrm{~N}_{3}$ by a HRESIMS peak at $m / z 246.1205[\mathrm{M}+\mathrm{Na}]^{+}$(calcd for $\mathrm{C}_{11} \mathrm{H}_{17} \mathrm{O}_{2} \mathrm{~N}_{3} \mathrm{Na}$, 246.1213) (Supplementary Figure S1). 1D (Table 1 and Supplementary Figures S2 and S3) and HSQC (Supplementary Figure S5) NMR spectra displayed one $\mathrm{sp}^{2}$ methine $\left(\delta_{\mathrm{C}} 120.8, \delta_{\mathrm{H}} 7.01\right)$, one $\mathrm{sp}^{3}$ methine $\left(\delta_{\mathrm{C}} 27.5, \delta_{\mathrm{H}} 1.91\right)$, three sp ${ }^{3}$ methylenes $\left(\delta_{\mathrm{C}} 27.6, \delta_{\mathrm{H}} 2.79 ; \delta_{\mathrm{C}} 31.1, \delta_{\mathrm{H}} 2.41 ; \delta_{\mathrm{C}} 38.4, \delta_{\mathrm{H}} 2.25\right)$, and two methyls $\left(\delta_{\mathrm{C}} 21.9, \delta_{\mathrm{H}} 0.86 ; \delta_{\mathrm{C}} 21.9, \delta_{\mathrm{H}} 0.84\right)$ (Table 1 ). The HMBC (Supplementary Figure $\mathrm{S} 7$ and Figure 2) correlations from $\mathrm{H}-7\left(\delta_{\mathrm{H}} 2.79\right), \mathrm{H}-8\left(\delta_{\mathrm{H}} 4.64\right)$, and $\mathrm{NH}_{2}\left(\delta_{\mathrm{H}} 7.30, \delta_{\mathrm{H}} 6.72\right)$ to carbonyl carbon $\left(\delta_{\mathrm{C}-9} 173.7\right)$ along with the ${ }^{1} \mathrm{H}-{ }^{1} \mathrm{H}$ COSY (Supplementary Figure $\mathrm{S} 6$ and Figure 2 ) between $\mathrm{H}-7$ 
and H-8 indicated a 3-substituted propionamide moiety. ${ }^{1} \mathrm{H}-{ }^{1} \mathrm{H}$ COSY correlations from $\mathrm{H}-10\left(\delta_{\mathrm{H}} 2.25\right)$ to $\mathrm{H}-12\left(\delta_{\mathrm{H}} 0.86\right)$, and $\mathrm{H}-13\left(\delta_{\mathrm{H}} 0.84\right)$ through $\mathrm{H}-11\left(\delta_{\mathrm{H}} 1.91\right)$, demonstrated an isobutyl fragment. The remaining fragment, $\mathrm{C}_{4} \mathrm{H}_{2} \mathrm{ON}_{2}$, could be a pyrazin-2(1H)-one nucleus from the HMBC correlations from $\mathrm{H}-4\left(\delta_{\mathrm{H}} 7.01\right)$ to $\mathrm{C}-3\left(\delta_{\mathrm{C}} 155.2\right)$ and C-6 $\left(\delta_{\mathrm{C}} 138.0\right)$. Furthermore, the key HMBC correlations from H-10 to C-5 $\left(\delta_{C} 120.8\right)$ and C-6, and H-7 to C-2 $\left(\delta_{C}\right.$ 156.2) and C-3, allowed for the linkage of the isobutyl to C-6 and the 3-substituted propionamide moiety to C-3, respectively. Thus, structure 1 was established as 3-[6-(2-methylpropyl)-2-oxo-1H-pyrazin-3-yl] propenamide, which was only recorded in the Aurora Fine Chemicals with ID number K13.052.726 without any physical and chemical properties reported. Consequently, $\mathbf{1}$ was identified as a new naturally occurring compound.

Table 1. ${ }^{1} \mathrm{H}(400 \mathrm{MHz})$ and ${ }^{13} \mathrm{C}(100 \mathrm{MHz})$ NMR data of $\mathbf{1}$ in DMSO- $d_{6}$ and 2 in $\mathrm{MeOH}-d_{4}$.

\begin{tabular}{|c|c|c|c|c|}
\hline \multirow{2}{*}{ No. } & \multicolumn{2}{|r|}{1} & \multicolumn{2}{|r|}{2} \\
\hline & $\delta_{C}$, Type & $\delta_{\mathrm{H}}$, Mult. $(J$ in $\mathrm{Hz})$ & $\delta_{C}$, Type & $\delta_{\mathrm{H}}$, Mult. $(J$ in $\mathrm{Hz})$ \\
\hline 1 & & $12.01, \mathrm{brs}$ & $165.7, \mathrm{C}$ & \\
\hline 2 & $156.2, \mathrm{C}$ & & & \\
\hline 3 & $155.2, \mathrm{C}$ & & $125.1, \mathrm{C}$ & \\
\hline 4 & & & 161.3, C & \\
\hline 5 & $120.8, \mathrm{CH}$ & $7.01, \mathrm{~s}$ & & \\
\hline 6 & 138.0, C & & $44.7, \mathrm{CH}_{2}$ & $3.96, \mathrm{~m} ; 3.72, \mathrm{~m}$ \\
\hline 7 & $27.6, \mathrm{CH}_{2}$ & $2.79, \mathrm{t}(7.5)$ & 29.0, $\mathrm{CH}_{2}$ & $1.93, \mathrm{~m} ; 2.41, \mathrm{~m}$ \\
\hline 8 & $31.1, \mathrm{CH}_{2}$ & $2.41, \mathrm{t}(7.5)$ & $76.4, \mathrm{CH}$ & $4.41, \mathrm{~m}$ \\
\hline 9 & $173.7, \mathrm{C}$ & & $91.0, \mathrm{C}$ & \\
\hline 10 & $38.4, \mathrm{CH}_{2}$ & $2.25, \mathrm{~d}(7.3)$ & $115.1, \mathrm{CH}$ & $7.29, \mathrm{~s}$ \\
\hline 11 & $27.5, \mathrm{CH}$ & $1.91, \mathrm{~m}$ & $104.5, \mathrm{C}$ & \\
\hline 12 & $21.9, \mathrm{CH}_{3}$ & $0.85, \mathrm{~d}(6.6)$ & $127.4, \mathrm{C}$ & \\
\hline 13 & $21.9, \mathrm{CH}_{3}$ & $0.85, \mathrm{~d}(6.6)$ & $120.2, \mathrm{CH}$ & 7.37, d (7.9) \\
\hline 14 & & & $121.3, \mathrm{CH}$ & $7.07, \mathrm{dd}(7.9,7.9)$ \\
\hline 15 & & & $122.6, \mathrm{CH}$ & 7.12, dd $(7.9,7.9)$ \\
\hline 16 & & & $112.6, \mathrm{CH}$ & $7.43, \mathrm{~d}(7.9)$ \\
\hline 17 & & & $136.8, \mathrm{C}$ & \\
\hline $\mathrm{NH}_{2}$ & & $6.72, \mathrm{~s} ; 7.30, \mathrm{~s}$ & & \\
\hline $19^{2}$ & & & $146.2, \mathrm{C}$ & \\
\hline 20 & & & $40.5, \mathrm{C}$ & \\
\hline 21 & & & $146.1, \mathrm{CH}$ & $6.11, \mathrm{dd}(17.3,10.6)$ \\
\hline 22 & & & $112.6, \mathrm{CH}_{2}$ & $5.10, \mathrm{~d}(10.6) ; 5.13, \mathrm{~d}(17.3)$ \\
\hline 23 & & & $28.1, \mathrm{CH}_{3}$ & $1.57, \mathrm{~s}$ \\
\hline 24 & & & $28.3, \mathrm{CH}_{3}$ & $1.54, \mathrm{~s}$ \\
\hline
\end{tabular}

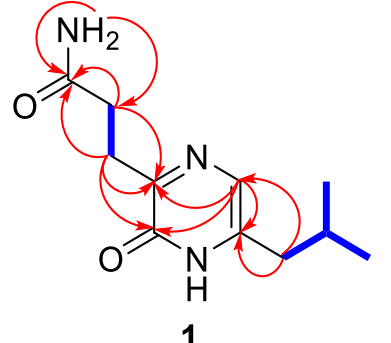

1
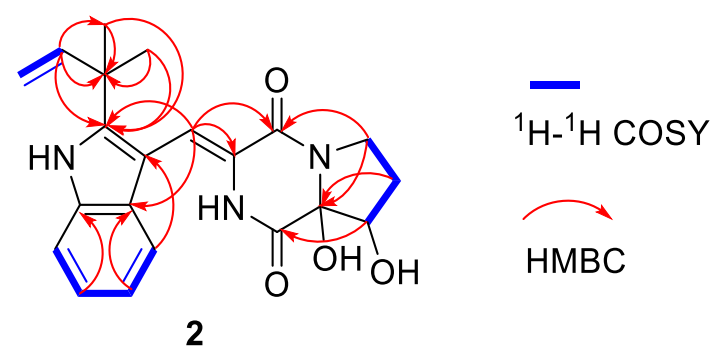

Figure 2. Key HMBC and ${ }^{1} \mathrm{H}-{ }^{1} \mathrm{H}$ COSY correlations of $\mathbf{1}$ and $\mathbf{2}$.

The racemic 2 was isolated as light yellow crystal with the molecular formula of $\mathrm{C}_{21} \mathrm{H}_{23} \mathrm{~N}_{3} \mathrm{O}_{4}$ from a HRESIMS peak at $m / z 404.1570[\mathrm{M}+\mathrm{Na}]^{+}$(calcd for $\mathrm{C}_{21} \mathrm{H}_{23} \mathrm{~N}_{3} \mathrm{O}_{4} \mathrm{Na}$, 404.1581) (Supplementary Figure S8). Its 1D (Table 1 and Supplementary Figures S9 and S10) and HSQC (Supplementary Figure S12) NMR spectra displayed two methyls $\left(\delta_{\mathrm{C}} 28.1, \delta_{\mathrm{H}} 1.57 ; \delta_{\mathrm{C}} 28.3, \delta_{\mathrm{H}} 1.54\right)$, two sp ${ }^{3}$ methylenes $\left(\delta_{\mathrm{C}} 44.7, \delta_{\mathrm{H}} 3.96, \delta_{\mathrm{H}} 3.72 ; \delta_{\mathrm{C}} 29.0, \delta_{\mathrm{H}} 1.93, \delta_{\mathrm{H}} 2.41\right)$, one sp ${ }^{3}$ methine $\left(\delta_{\mathrm{C}} 76.4, \delta_{\mathrm{H}} 4.41\right)$, five sp ${ }^{2}$ methines $\left(\delta_{\mathrm{C}} 115.1, \delta_{\mathrm{H}} 7.29 ; \delta_{\mathrm{C}} 120.2, \delta_{\mathrm{H}} 7.37 ; \delta_{\mathrm{C}} 121.3, \delta_{\mathrm{H}} 7.07 ; \delta_{\mathrm{C}} 122.6, \delta_{\mathrm{H}} 7.12 ; \delta_{\mathrm{C}} 122.6, \delta_{\mathrm{H}} 7.43\right)$, and 
one $\mathrm{sp}^{2}$ methylene $\left(\delta_{\mathrm{C}} 112.6, \delta_{\mathrm{H}} 5.10,5.13\right)$, which demonstrated the presence of a monosubstituted double bond (Table 1). ${ }^{1} \mathrm{H}-{ }^{1} \mathrm{H}$ COSY (Supplementary Figure S13 and Figure 2) from H-21 $\left(\delta_{\mathrm{H}} 6.11\right.$ ) to H-22 $\left(\delta_{\mathrm{H}} 5.10 ; \delta_{\mathrm{H}} 5.13\right)$ and the HMBC (Supplementary Figure S14 and Figure 2$)$ from H-21 $\left(\delta_{\mathrm{H}}\right.$ 6.11) to $C-20\left(\delta_{C} 40.5\right), C-23\left(\delta_{C} 28.1\right)$, and $C-24\left(\delta_{C} 28.3\right)$, along with $\mathrm{H}-23\left(\delta_{\mathrm{H}} 1.57\right)$ to $\mathrm{C}-20$ and $\mathrm{C}-24$, which demonstrated the presence of a 2-methylbut-3-en-2-yl fragment. The ${ }^{1} \mathrm{H}-{ }^{1} \mathrm{H}$ COSY correlations from $\mathrm{H}-13\left(\delta_{\mathrm{H}} 7.37\right)$ to $\mathrm{H}-16\left(\delta_{\mathrm{H}} 7.43\right)$, along with the HMBC from $\mathrm{H}-13\left(\delta_{\mathrm{H}} 7.37\right)$ to C-12 $\left(\delta_{C} 127.4\right), C-11\left(\delta_{C} 104.5\right)$, and C-17 $\left(\delta_{C} 127.4\right)$, and H-16 $\left(\delta_{\mathrm{H}} 7.43\right)$ to C-12 and C-17, which demonstrated the presence of a 2,3-bisubstituted indole ring. Moreover, the key HMBC from H-21, $\mathrm{H}-23$, and $\mathrm{H}-24\left(\delta_{\mathrm{H}} 1.54\right)$ to $\mathrm{C}-19\left(\delta_{\mathrm{C}} 146.2\right)$ connected the 2-methylbut-3-en-2-yl group to $\mathrm{C}-19$ of the indole ring. Chemical shifts of $C-1\left(\delta_{C} 165.7\right)$ and C-4 $\left(\delta_{C} 161.3\right)$ indicated two amide carbonyl carbons. In addition, ${ }^{1} \mathrm{H}-{ }^{1} \mathrm{H}$ COSY correlations from $\mathrm{H}-6\left(\delta_{\mathrm{H}} 3.72 ; \delta_{\mathrm{H}} 3.96\right)$ to $\mathrm{H}-8\left(\delta_{\mathrm{H}} 4.41\right)$ through $\mathrm{H}-7\left(\delta_{\mathrm{H}} 1.93 ; \delta_{\mathrm{H}} 2.41\right)$ and HMBC correlations from H-6 to C-4 and C-9 $\left(\delta_{\mathrm{C}} 91.0\right), \mathrm{H}-7$ to C-9, H-8 $\left(\delta_{\mathrm{H}} 4.41\right)$ to $\mathrm{C}-1$ and $\mathrm{C}-9$ and, $\mathrm{H}-10\left(\delta_{\mathrm{H}} 7.29\right)$ to $\mathrm{C}-3\left(\delta_{\mathrm{C}} 125.1\right)$ and $\mathrm{C}-4$ were observed. This data indicated a 2-methylene-(2,3-dihydroxytetrahydro) pyrrolo[1,2-a] diketopiperazine nucleus. The key HMBC correlations from H-10 to C-11, C-12, and C-19 (Figure 2) allowed for the linkage of the isopentenylindole and tetrahydropyrrolo[1,2-a] diketopiperazine moieties by a C-11-C-10 sigma bond. Thus, the planar structure of 2 was determined as 9-hydroxybrevianamide $\mathrm{Q}$. A literature survey showed that $\mathbf{2}$ has the same planar structure as brevianamide $\mathrm{U}$ without resolution of the configuration $\left([\alpha]_{\mathrm{D}}^{21}+20(c 0.17, \mathrm{MeOH})\right)$ [21]. Although their ${ }^{1} \mathrm{H}$ and ${ }^{13} \mathrm{C}$ NMR data were similar, they displayed obvious different chemical shifts of C-1 and C-9 in ${ }^{13} \mathrm{C} N M R$, indicating the different configurations. The configuration of $\mathbf{2}$ was confirmed by $\mathrm{X}$-ray single crystallographic diffraction that clearly indicated trans-configuration between 8-OH and 9-OH and the Z-geometry of the $\Delta^{3(10)}$-double bond (Figure 3). However, the X-ray crystallographic results were space group P-1 and the planus line of the electronic circular dichroism (ECD) spectrum indicated 2 might be a pair of enantiomers. Thus, two enantiomers with 1.1:1 ratio of HPLC peaks area were separated by a chiral column (Supplementary Figure S15A), whose specific rotations were $[\alpha]_{\mathrm{D}}^{25}+44$ and $-40(c 0.05, \mathrm{MeOH})$, respectively. The absolute configurations of (+)-2 and (-)-2 were respectively assigned as $(8 S, 9 S)$ and $(8 R, 9 R)$ by comparing the experimental and calculated ECD values obtained using TD-DFT at the B3LYP/6-31G(d) level $[19,28,29]$ (Figure 4). Therefore, we named (+)-2 and (-)-2 as (+)-brevianamide $X$ and (-)-brevianamide $X$, respectively.

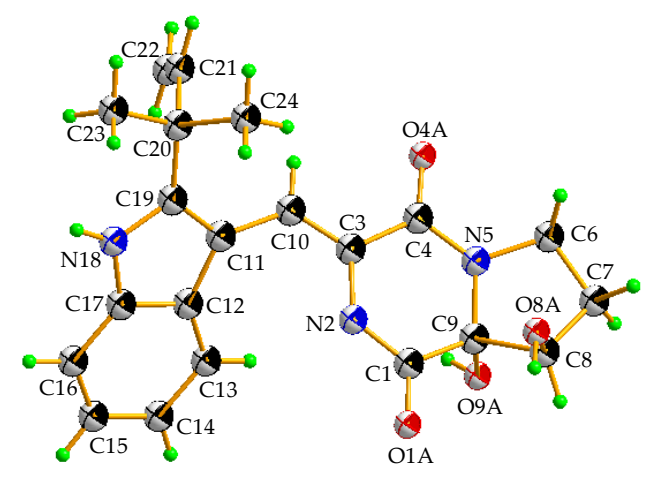

Figure 3. X-ray crystallographic structure of 2.

The planar structures of compounds 3-5 were reported previously without assignment of the absolute configurations $[20,22]$. Their small specific rotations, $[\alpha]_{\mathrm{D}}^{25}+10(c 0.82, \mathrm{MeOH})$ for $3,[\alpha]_{\mathrm{D}}^{25}-7$ (c 1.75, MeOH) for 4, and $[\alpha]_{\mathrm{D}}^{25}+19($ c $0.33, \mathrm{MeOH})$ for 5 , indicated that compounds 3-5 might be enantiomeric mixtures, perhaps having an excess of one of the enantiomers. They were analyzed and resolved by chiral HPLC. As we expected, $( \pm)-3,( \pm)-4$, and $( \pm)-5$ were further separated into their optically pure enantiomers (Supplementary Figure S15B-D). The absolute configurations were determined by comparing the experimental ECD with those calculated using TD-DFT at the 
B3LYP/6-31G(d) level (Figure 4). As a result, compounds (+)-3 and 4 were assigned to have a $9 R$-configuration, while the (-)-3 and 4 were assigned a 9S-configuration. This is the first time that racemic brevianamides $R(3), Q(4)$, and V (5) have been resolved into their chiral enantiomers and their absolute configurations have been determined.
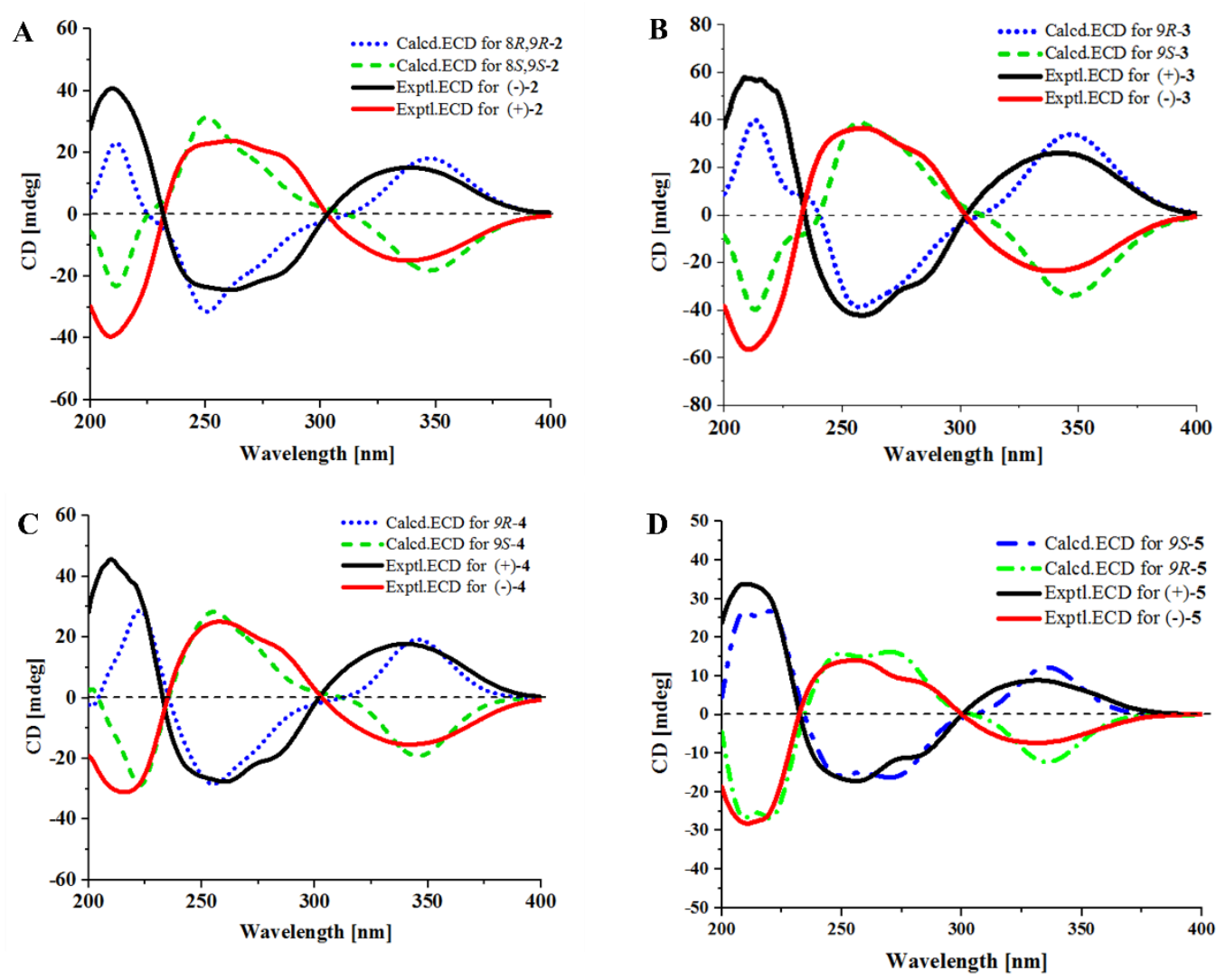

Figure 4. Experimental and calculated ECD spectra of 2 (A), 3 (B), 4 (C) and 5 (D).

The structures of $\mathbf{6 - 1 1}$ were determined by comparing their NMR data and specific rotations those reported [23-25]. Although the structure of $\mathbf{1 2}$ has been previously reported in the references, there were no ${ }^{13} \mathrm{C} \mathrm{NMR}$ data [26] and nor NMR solvent reported [27], and chemical shifts of 12 (Table 2) were obviously different to those in ref. [27]. The difficulty was in the assignment of the position of the methoxycarbonyl group at C-2' or C $-4^{\prime}$. Thus, its dimethyl ether (12a) was prepared from 12 by reaction with $\mathrm{MeI} / \mathrm{K}_{2} \mathrm{CO}_{3}$ and the $2 \mathrm{D} \mathrm{NMR}$ of both 12 (Supplementary Figures S21-S23) and 12a (Supplementary Figures S27-S29) were recorded. The ROESY correlations of $\mathrm{CH}_{3} \mathrm{O}-5^{\prime}\left(\delta_{\mathrm{H}} 3.72\right)$ with $\mathrm{H}-6^{\prime}\left(\delta_{\mathrm{H}} 6.61\right)$ and the protons $\left(\delta_{\mathrm{H}} 3.78\right)$ of the methyl ester in 12a (Supplementary Figure S28 and Figure 5) located the methoxycarbonyl group at C- $4^{\prime}$. Therefore, the structures of compounds 12 and 12a were determined as methyl diorcinol-4-carboxylate and methyl 3,3'-di(O-methyl) diorcinol-4-carboxylate, respectively.

A plausible biosynthetic relationship linking 2-6 through a sequence of oxidative transformations and hydrolysis or methanolysis is illustrated in Figure 6. Positions 8 and 9 in 6 have no steric hindrance when performing electrophilic addition or oxidation. Therefore, it is easy to form enantiomeric mixtures or excess of 2-5. 
Table 2. ${ }^{1} \mathrm{H}(400 \mathrm{MHz})$ and ${ }^{13} \mathrm{C}(100 \mathrm{MHz}) \mathrm{NMR}$ data of 12 and 12a in DMSO- $d_{6}$.

\begin{tabular}{|c|c|c|c|c|c|c|}
\hline \multirow[b]{2}{*}{ No. } & \multicolumn{2}{|c|}{12} & \multicolumn{2}{|c|}{$12 a$} & \multicolumn{2}{|c|}{12 [27] } \\
\hline & $\delta_{C}$, Type & $\begin{array}{l}\mathcal{\delta}_{\mathrm{H}}, \text { Mult. } \\
(J \text { in } \mathrm{Hz})\end{array}$ & $\delta_{C}$, Type & $\begin{array}{l}\delta_{\mathrm{H}}, \text { Mult. } \\
(J \text { in } \mathrm{Hz})\end{array}$ & $\delta_{C}$, Type & $\begin{array}{l}\delta_{\mathrm{H}}, \text { Mult. } \\
(J \text { in } \mathrm{Hz})\end{array}$ \\
\hline 1 & 156.4, C & & 156.9, C & & $155.9, \mathrm{C}$ & \\
\hline 2 & $103.8, \mathrm{CH}$ & $\begin{array}{c}\text { 6.22, dd (1.2, } \\
1.2)\end{array}$ & $102.3, \mathrm{CH}$ & $6.42, \mathrm{~d}(1.2)$ & $105.0, \mathrm{CH}$ & 6.44, brs \\
\hline 3 & 158.6, C & & $160.5, \mathrm{C}$ & & $156.8, \mathrm{C}$ & \\
\hline 4 & $112.1, \mathrm{CH}$ & 6.41 , brs & $110.4, \mathrm{CH}$ & $6.58, \mathrm{brs}$ & $112.6, \mathrm{CH}$ & 6.49, brs \\
\hline 5 & $140.5, \mathrm{C}$ & & $140.6, \mathrm{C}$ & & 141.2, C & \\
\hline 6 & $110.8, \mathrm{CH}$ & 6.30 , brs & 111.7, CH & $6.42, \mathrm{~d}(1.2)$ & $113.4, \mathrm{CH}$ & 6.37 , brs \\
\hline $1^{\prime}$ & 159.1, C & & $158.4, \mathrm{C}$ & & $162.3, \mathrm{C}$ & \\
\hline $2^{\prime}$ & $110.9, \mathrm{CH}$ & $6.35, \mathrm{~d}(2.1)$ & $111.2, \mathrm{CH}$ & $6.40, \mathrm{~d}(2.1)$ & $113.0, \mathrm{CH}$ & $6.37, \mathrm{~d}(2.5)$ \\
\hline $3^{\prime}$ & $139.1, \mathrm{C}$ & & $137.5, \mathrm{C}$ & & $143.6, \mathrm{C}$ & \\
\hline $4^{\prime}$ & $114.8, \mathrm{C}$ & & $118.6, \mathrm{C}$ & & $107.0, \mathrm{CH}$ & \\
\hline $5^{\prime}$ & 157.7, C & & 157.6, C & & 165.0, C & \\
\hline $6^{\prime}$ & 102.7, CH & $6.27, \mathrm{~d}(2.1)$ & $100.2, \mathrm{CH}$ & $6.61, \mathrm{~d}(2.1)$ & 103.2, CH & $6.34, \mathrm{~d}(2.5)$ \\
\hline $1^{\prime \prime}$ & $168.6, \mathrm{C}$ & & $167.6, \mathrm{C}$ & & $172.0, \mathrm{C}$ & \\
\hline $5-\mathrm{Me}$ & 21.1, $\mathrm{CH}_{3}$ & $2.20, \mathrm{~s}$ & 21.2, $\mathrm{CH}_{3}$ & $2.25, \mathrm{~s}$ & 21.4, $\mathrm{CH}_{3}$ & $2.28, \mathrm{~s}$ \\
\hline $3^{\prime}-\mathrm{Me}$ & $20.2, \mathrm{CH}_{3}$ & $2.21, \mathrm{~s}$ & $19.0, \mathrm{CH}_{3}$ & $2.14, \mathrm{~s}$ & $24.2, \mathrm{CH}_{3}$ & $2.50, \mathrm{~s}$ \\
\hline 3-OMe & & & $55.3, \mathrm{CH}_{3}$ & $3.72, \mathrm{~s}$ & & \\
\hline $5^{\prime}-\mathrm{OMe}$ & & & $56.0, \mathrm{CH}_{3}$ & $3.72, \mathrm{~s}$ & & \\
\hline $1^{\prime \prime}-\mathrm{OMe}$ & $51.9, \mathrm{CH}_{3}$ & $3.78, \mathrm{~s}$ & $52.1, \mathrm{CH}_{3}$ & $3.78, \mathrm{~s}$ & $51.9, \mathrm{CH}_{3}$ & $3.94, \mathrm{~s}$ \\
\hline 3-OH & & 10.21 , brs & & & & $11.66, \mathrm{~s}$ \\
\hline $5^{\prime}-\mathrm{OH}$ & & 9.61 , brs & & & & \\
\hline
\end{tabular}

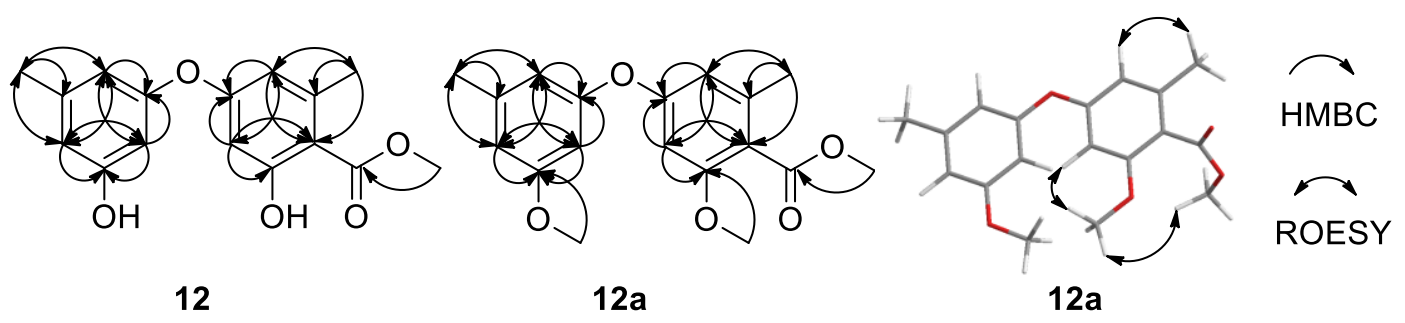

Figure 5. HMBC correlations of $\mathbf{1 2}$ and 12a, and key ROESY correlations of 12a.<smiles>[R]Oc1ccc2[nH]c(C(C)(C)C=C)c(/C=C3\NC(=O)C4([R])CCCN4C3=O)c2c1/C=c1\[nH]c(=O)/c(=C/c2c(C(C)(C)C=C)[nH]c3ccccc23)[nH]c1=O</smiles>

Figure 6. Plausible biosynthetic relationship among 2-6.

HPLC-UV was used to identify which compounds are solely produced under SAHA. Both extracts, generated with and without addition of SAHA, were analyzed using the same elution gradient. Compared to those in the same medium without SAHA, epigenetic modification with SAHA enhanced the NP diversity of $A$. versicolor OUCMDZ-2738 and the compounds 1-4, 8, 9, 11, and 12 were solely observed under SAHA condition. This demonstrated SAHA as the actual inducer to 
produce compounds 1-4, 8, 9, 11, and 12 (Supplementary Figure S31 and Figure 7), further indicating that chemically epigenetic regulation is an effective method for expanding the chemical space of fungal natural products.

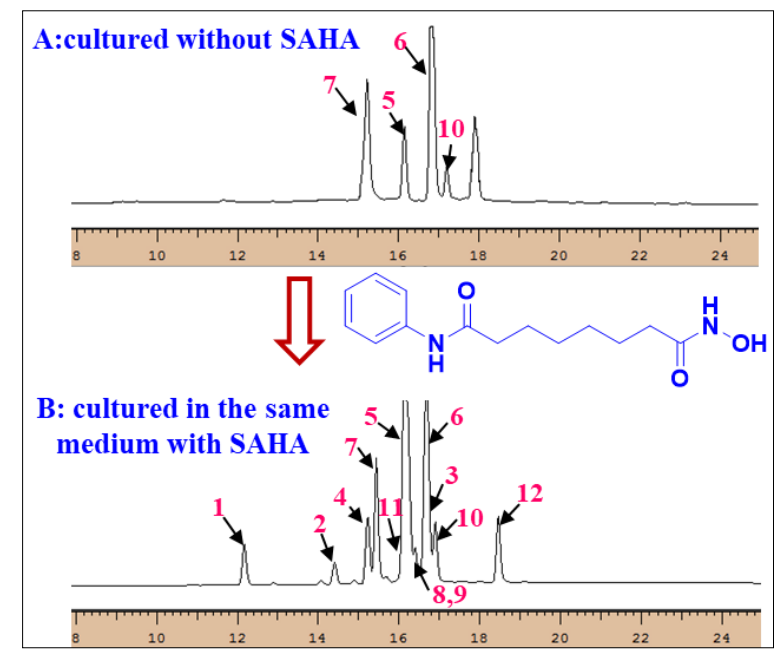

Figure 7. HPLC-UV profiles of the fungal metabolites with and without SAHA.

All the isolated compounds (1-12) were evaluated for antibacterial activity against a panel of pathogenic microorganisms, including four Gram-positive bacteria, (Bacillus subtilis ATCC6051, Clostridium perfringens ATCC13048, Staphylococcus aureus ATCC6538, and Staphylococcus aureus ATCC25923), two Gram-negative bacteria (Pseudomonas aeruginosa ATCC10145 and Escherichia coli ATCC11775), and two pathogenic fungi (Candida albicans ATCC10231, Candida glabrata ATCC2001). The results showed that compound $\mathbf{1 1}$ selectively inhibited $P$. aeruginosa while $\mathbf{1 2}$ inhibited P. aeruginosa and C. glabrata with MIC values of 17.4, 13.9, and $27.8 \mu \mathrm{M}$, respectively (Table 3). The inhibitory activities of 1-12 against $\alpha$-glucosidase from Saccharomyces cerevisiae were also evaluated using the pNPG method. Only compounds 9-11 displayed $\alpha$-glucosidase inhibitory activity with $\mathrm{IC}_{50}$ values of 117.3, 237.4 and $275.3 \mu \mathrm{M}$, respectively. Acarbose, used as the assay control, had an $\mathrm{IC}_{50}$ of $255.3 \mu \mathrm{M}$.

Table 3. Antimicrobial bioassay results of active compounds.

\begin{tabular}{|c|c|c|c|c|c|c|c|c|}
\hline \multirow{2}{*}{ Compounds } & \multicolumn{8}{|c|}{ MIC $(\mu \mathrm{M})$} \\
\hline & B. subtilis & P. aeruginosa & C. perfringens & S. aureus ${ }^{\text {a }}$ & E. coli & S. aureus ${ }^{\text {b }}$ & C. albicans & C. glabrata \\
\hline 1 & $>200$ & $>200$ & $>200$ & $>200$ & $>200$ & $>200$ & $>200$ & $>200$ \\
\hline 2 & $>200$ & $>200$ & $>200$ & $>200$ & $>200$ & $>200$ & $>200$ & $>200$ \\
\hline 3 & $>200$ & $>200$ & $>200$ & $>200$ & $>200$ & $>200$ & $>200$ & $>200$ \\
\hline 4 & $>200$ & $>200$ & $>200$ & $>200$ & $>200$ & $>200$ & $>200$ & $>200$ \\
\hline 5 & $>200$ & $>200$ & $>200$ & $>200$ & $>200$ & $>200$ & $>200$ & $>200$ \\
\hline 6 & $>200$ & 92.2 & $>200$ & 184.4 & $>200$ & 184.4 & $>200$ & $>200$ \\
\hline 7 & $>200$ & $>200$ & $>200$ & $>200$ & $>200$ & $>200$ & $>200$ & $>200$ \\
\hline 8 & $>200$ & 46.2 & $>200$ & $>200$ & $>200$ & 184.8 & $>200$ & $>200$ \\
\hline 9 & $>200$ & 101.9 & $>200$ & $>200$ & $>200$ & $>200$ & $>200$ & $>200$ \\
\hline 10 & $>200$ & 50.9 & $>200$ & $>200$ & $>200$ & $>200$ & $>200$ & $>200$ \\
\hline 11 & 69.6 & 17.4 & 139.2 & $>200$ & $>200$ & $>200$ & $>200$ & $>200$ \\
\hline 12 & $>128$ & 13.9 & 55.6 & $>200$ & $>200$ & 55.6 & 111.2 & 27.8 \\
\hline Ciprofloxacin & 48.4 & 96.8 & 0.75 & 0.75 & 12.1 & 0.75 & ND & ND \\
\hline Ketoconazole & ND & ND & ND & ND & ND & ND & 7.6 & 3.8 \\
\hline
\end{tabular}

\section{Materials and Methods}

\subsection{General Experimental Procedures}

Optical rotations were measured using an AUTOPOL1 polarimeter (Rudolph Research Analytical, Hackettstown, NJ, USA). UV spectra were measured on a Beckman DU 640 
spectrophotometer (Beckman Coulter, Inc., Brea, CA, USA). ECD spectra were measured on JASCOJ-715 spectropolarimeter (JASCO Corporation, Tokyo, Japan). IR spectra were taken on a Nicolet Nexus 470 spectrophotometer (Thermo Nicolet Corporation, Madison, WI, USA) as KBr disks. 1D (one-dimensional) and 2D (two-dimensional) NMR spectra were recorded on an INOVA-400MHz spectrometer with TMS (tetramethylsilane) as the internal standard. ESIMS and HRESIMS were carried out on a Waters 2695 LCQ-MS liquid chromatography mass spectrometer (Thermo Finnigan, San Francisco, CA, USA). Semi-preparative HPLC separations were performed using a Hitachi Primaide Organizer HPLC system (Hitachi High-Tech Science Corporation, Tokyo, Japan). YMC-Pack ODS-A column $(\mathrm{S}-5 \mu \mathrm{m}, 12 \mathrm{~nm}, 250 \times 4.6 \mathrm{~mm}$ and S-5 $\mu \mathrm{m}, 12 \mathrm{~nm}, 250 \times 10 \mathrm{~mm}$, Shenzhen Chemist Technology Co. Ltd., Shenzhen, China). Chiral column (Lux ${ }^{\circledR} 5 \mu \mathrm{m}$ Cellulose-2 and Lux ${ }^{\circledR} 5 \mu \mathrm{m}$ i-Cellulose-5, LC Column $250 \times 4.6 \mathrm{~mm}$., Phenomenex, CA, USA). Thin layer chromatography (TLC) and column chromatography (CC) were performed on plates precoated with silica gel GF $254(10-40 \mu \mathrm{m})$ and over silica gel (200-300 mesh, Qingdao Marine Chemical Factory, Qingdao, China), respectively. Chemical reagents for isolation were analytical grade (Tianjin Kaixin Chemical Industry Co., Ltd., Tianjin, China); chromatographic grade MeOH for HPLC was from Tianjin Siyou Fine Chemicals Co., Ltd., Tianjin, China.

\subsection{Fungal Material}

The fungus Aspergillus versicolor OUCMDZ-2738 was isolated from a piece of fresh tissue from the Enteromorpha prolifera, collected from the Shilaoren beach, Qingdao, China, in July 2012 [12,13]. The pure cultures were deposited in the Key Laboratory of Marine Drugs, School of Medicine and Pharmacy, Ocean University of China, Qingdao, Shandong province, China, with the GenBank (NCBI) accession number MH150818.

\subsection{Cultivation and Extraction of Strain OUCMDZ-2738}

The cultivation and extraction process were the same described in previous papers [12,13], and the EtOAc solutions were concentrated under reduced pressure to give a crude extract $(13.1 \mathrm{~g})$.

\subsection{Purification}

The crude extract was applied to a silica gel (200-300 mesh) column and was separated into twelve fractions (Fr.1 to Fr.12) using a step-gradient elution of petroleum ether/EtOAc (0-100\%) and $\mathrm{CHCl}_{3} / \mathrm{MeOH}$.

Fr.1 (0.2 g) was purified by semipreparative $\mathrm{HPLC}\left(50: 50 \mathrm{MeOH} / \mathrm{H}_{2} \mathrm{O}, 4 \mathrm{~mL} / \mathrm{min}\right)$ to give $\mathbf{1}$ (11.6 $\left.\mathrm{mg}, t_{\mathrm{R}} 9.6 \mathrm{~min}\right)$. Fr.12 (0.24 g) was purified by semipreparative HPLC $\left(70: 30 \mathrm{MeOH} / \mathrm{H}_{2} \mathrm{O}, 4 \mathrm{~mL} / \mathrm{min}\right)$ to give the racemic-2 $\left(8.0 \mathrm{mg}, t_{\mathrm{R}} 6.5 \mathrm{~min}\right)$. Fr.7 $(0.85 \mathrm{~g})$ was separated on a preparative TLC eluted with $\mathrm{CH}_{2} \mathrm{Cl}_{2} / \mathrm{CH}_{3} \mathrm{OH}(v / v, 30: 1)$, then subfraction Fr.7-1 (142.0 mg) was purified by semipreparative HPLC (70:30 MeOH/ $\left.\mathrm{H}_{2} \mathrm{O}, 4 \mathrm{~mL} / \mathrm{min}\right)$ to give compound 6 (78.6 mg, $\left.t_{\mathrm{R}} 6.4 \mathrm{~min}\right)$. Subfraction Fr.7-3 (101 mg) was purified by semipreparative $\mathrm{HPLC}\left(50: 50 \mathrm{MeOH} / \mathrm{H}_{2} \mathrm{O}, 4 \mathrm{~mL} / \mathrm{min}\right)$ to give racemic- $4(9.3 \mathrm{mg}$, $\left.t_{\mathrm{R}} 8.3 \mathrm{~min}\right)$. Subfraction Fr.7-4 $(75 \mathrm{mg})$ was purified by semipreparative HPLC $\left(60: 40 \mathrm{MeOH} / \mathrm{H}_{2} \mathrm{O}\right.$, $4 \mathrm{~mL} / \mathrm{min})$ to give $9\left(10.5 \mathrm{mg}, t_{\mathrm{R}} 7.0 \mathrm{~min}\right)$ and 8 (5.3 mg, $\left.t_{\mathrm{R}} 8.1 \mathrm{~min}\right)$. Fr.8 (0.42 g) was separated on a preparative TLC eluted with $\mathrm{CH}_{2} \mathrm{Cl}_{2} / \mathrm{MeOH}(v / v, 50: 1)$, then subfraction Fr.8-1 (178.3 mg) was purified by semipreparative $\mathrm{HPLC}\left(65: 35 \mathrm{MeOH} / \mathrm{H}_{2} \mathrm{O}, 4 \mathrm{~mL} / \mathrm{min}\right)$ to give racemic-3 $\left(7.3 \mathrm{mg}\right.$, $t_{\mathrm{R}}$ $8.0 \mathrm{~min})$ and racemic-5 $\left(90.0 \mathrm{mg}, t_{\mathrm{R}} 8.5 \mathrm{~min}\right)$. Fr.5 $(0.21 \mathrm{~g})$ was purified by semipreparative HPLC (70:30 $\left.\mathrm{MeOH} / \mathrm{H}_{2} \mathrm{O}, 4 \mathrm{~mL} / \mathrm{min}\right)$ to give $7\left(40.8 \mathrm{mg}, t_{\mathrm{R}} 9.7 \mathrm{~min}\right)$ and $10\left(9.8 \mathrm{mg}, t_{\mathrm{R}} 8.7 \mathrm{~min}\right)$. Fr.4 (0.12 g) was purified by semipreparative $\mathrm{HPLC}\left(65: 35 \mathrm{MeOH} / \mathrm{H}_{2} \mathrm{O}, 4 \mathrm{~mL} / \mathrm{min}\right)$ to give 11 (14.6 $\left.\mathrm{mg}, t_{\mathrm{R}} 6.7 \mathrm{~min}\right)$. Fr.2 $(0.18 \mathrm{~g})$ was purified by semipreparative HPLC $\left(70: 30 \mathrm{MeOH} / \mathrm{H}_{2} \mathrm{O}, 4 \mathrm{~mL} / \mathrm{min}\right)$ to give $12(48.6$ $\left.\mathrm{mg}, t_{\mathrm{R}} 7.3 \mathrm{~min}\right)$. The racemic-2 was resolved as the optically pure $(+)-2\left(1.0 \mathrm{mg}, t_{\mathrm{R}} 13.7 \mathrm{~min}\right)$ and (-)-2 $\left(1.1 \mathrm{mg}, t_{\mathrm{R}} 10.5 \mathrm{~min}\right)$ by semi-preparative HPLC $\left(25: 75 \mathrm{MeCN} / \mathrm{H}_{2} \mathrm{O}, 0.9 \mathrm{~mL} / \mathrm{min}\right)$ equipped with a chiral column (Lux ${ }^{\circledR} 5 \mathrm{~m}$ Cellulose-2, LC Column $250 \times 4.6 \mathrm{~mm}$, Phenomenex). Using the same procedure, the racemic 3 and 4 were chirally separated as the optically pure (-)-3 (1.3 mg, $\left.t_{R} 6.5 \mathrm{~min}\right)$, 
(+)-3 (1.5 mg, $\left.t_{\mathrm{R}} 5.7 \mathrm{~min}\right),(+)-4\left(2.1 \mathrm{mg}, t_{\mathrm{R}} 4.3 \mathrm{~min}\right)$ and (-)-4 (2.2 mg, $\left.t_{\mathrm{R}} 4.8 \mathrm{~min}\right)$ by a chiral HPLC column (80:20 MeOH/ $\left.\mathrm{H}_{2} \mathrm{O}, 0.9 \mathrm{~mL} / \mathrm{min}\right)(+)-5\left(35.6 \mathrm{mg}, t_{\mathrm{R}} 7.1 \mathrm{~min}\right)$ and (-)-5 (20.9 mg, $\left.t_{\mathrm{R}} 9.8 \mathrm{~min}\right)$ were chirally separated by semi-preparative $\operatorname{HPLC}\left(80: 20 \mathrm{MeOH} / \mathrm{H}_{2} \mathrm{O}, 0.9 \mathrm{~mL} / \mathrm{min}\right)$ equipped with a chiral column (Lux ${ }^{\circledR} 5 \mu \mathrm{m}$ i-Cellulose-5, LC Column $250 \times 4.6 \mathrm{~mm}$, Phenomenex).

3-[6-(2-Methylpropyl)-2-oxo-1H-pyrazin-3-yl]propanamide (1): a brown amorphous powder, $\mathrm{mp}$ 141-143 ${ }^{\circ} \mathrm{C}$; UV (MeOH) $\lambda_{\max }(\log \varepsilon) 217$ (3.75), 230 (3.79), 262 (3.15), 325 (3.66) nm; IR (KBr) $v_{\max }$ 3400, 3198, 2959, 2929, 2861, 1655, 1614, 1529, 1408, 1168, $575 \mathrm{~cm}^{-1} ;{ }^{1} \mathrm{H}$ and ${ }^{13} \mathrm{C}$ NMR data (Table 1); HRESIMS $m / z 246.1205[\mathrm{M}+\mathrm{Na}]^{+}$(calculated for $\mathrm{C}_{11} \mathrm{H}_{17} \mathrm{O}_{2} \mathrm{~N}_{3} \mathrm{Na}$, 246.1213).

$( \pm)$-Brevianamide X (2): light yellow crystal; UV (MeOH) $\lambda_{\max }(\log \varepsilon) 233$ (4.34), 245 (4.33), 287 (4.18), 329 (4.19), 357 (4.20) nm; IR (KBr) $v_{\max } 3351,2968,1684,1620,1427,1326,1244,1107,1062,1022$, 979, 960, 921, 749, 655, 584, $518 \mathrm{~cm}^{-1} ;{ }^{1} \mathrm{H}$ and ${ }^{13} \mathrm{C}$ NMR data (Table 1); ESI-MS $m / z 404[\mathrm{M}+\mathrm{Na}]^{+}$; HRESIMS $m / z 404.1570[\mathrm{M}+\mathrm{Na}]^{+}$(calculated for $\mathrm{C}_{11} \mathrm{H}_{17} \mathrm{O}_{2} \mathrm{~N}_{3} \mathrm{Na}$, 404.1581). (+)-2: $\mathrm{mp} 241-243{ }^{\circ} \mathrm{C}$; $[\alpha]_{\mathrm{D}}^{25}+44\left(c\right.$ 0.05, MeOH); $\mathrm{ECD}(0.0014 \mathrm{M}, \mathrm{MeOH}) \lambda_{\max }(\Delta \varepsilon) 208.5(-6.5), 261(+3.9), 337(-2.5) \mathrm{nm}$. (-)-2: $\mathrm{mp} 220-222{ }^{\circ} \mathrm{C} ;[\alpha]_{\mathrm{D}}^{25}-40(c 0.05, \mathrm{MeOH}) ; \mathrm{ECD}(0.001 \mathrm{M}, \mathrm{MeOH}) \lambda_{\max }(\Delta \varepsilon) 208.5(+6.4), 261(-3.8)$, $337(+2.4) \mathrm{nm}$.

( \pm )-Brevianamide $\mathrm{R}(3)$ : a colorless powder; ESI-MS $m / z$ 402.2 [M $+\mathrm{Na}]^{+} ;{ }^{1} \mathrm{H}$ and ${ }^{13} \mathrm{C}$ NMR (see supporting information). (+)-3: $\mathrm{mp} 121-123^{\circ} \mathrm{C} ;[\alpha]_{\mathrm{D}}^{25}+208(c 0.15, \mathrm{MeOH}) ; \mathrm{ECD}(0.007 \mathrm{M}, \mathrm{MeOH}) \lambda_{\max }$ $(\Delta \varepsilon) 212(+26.2), 258(-19.1), 342(+11.8)$ nm. (-)-3: mp 140-142 ${ }^{\circ} \mathrm{C} ;[\alpha]_{\mathrm{D}}^{25}-213(c 0.13, \mathrm{MeOH})$; ECD $(0.007 \mathrm{M}, \mathrm{MeOH}) \lambda_{\max }(\Delta \varepsilon) 212(-25.9), 258(+16.7), 340.5(-10.8) \mathrm{nm}$.

$\left( \pm\right.$ )-Brevianamide $\mathrm{Q}(4)$ : a colorless powder; ESI-MS $m / z 388.2[\mathrm{M}+\mathrm{Na}]^{+} ;{ }^{1} \mathrm{H}$ and ${ }^{13} \mathrm{C}$ NMR (see supporting information). (+)-4: $\mathrm{mp} 141-143^{\circ} \mathrm{C} ;[\alpha]_{\mathrm{D}}^{25}+105\left(c\right.$ 0.2, MeOH); $\mathrm{ECD}(0.003 \mathrm{M}, \mathrm{MeOH}) \lambda_{\max }$ ( $\Delta \varepsilon) 212(+21.8), 258(-14.3), 340(+9.3) \mathrm{nm} .(-)-4: \mathrm{mp} 160-163{ }^{\circ} \mathrm{C} ;[\alpha]_{\mathrm{D}}^{25}-109(c 0.2, \mathrm{MeOH}) ; \mathrm{ECD}(0.003$ $\mathrm{M}, \mathrm{MeOH}) \lambda_{\max }(\Delta \varepsilon) 213(-19.3), 258(+15.8), 340(-9.7) \mathrm{nm}$.

( \pm )-Brevianamide V (5): a light yellow powder; ESI-MS $m / z 372.3[\mathrm{M}+\mathrm{Na}]^{+} ;{ }^{1} \mathrm{H}$ and ${ }^{13} \mathrm{C} \mathrm{NMR}$ (see supporting information). (+)-5: mp 128-130 ${ }^{\circ} \mathrm{C} ;[\alpha]_{\mathrm{D}}^{25}+40\left(\right.$ c 2.0, MeOH); $\mathrm{ECD}(0.0014 \mathrm{M}, \mathrm{MeOH}) \lambda_{\max }$ $(\Delta \varepsilon) 212(+24.3), 258(-12.2), 330(+6.3)$ nm. (-)-5: mp 131-132 ${ }^{\circ} \mathrm{C} ;[\alpha]_{\mathrm{D}}^{25}-38($ c 2.0, MeOH); ECD $(0.001$ $\mathrm{M}, \mathrm{MeOH}) \lambda_{\max }(\Delta \varepsilon) 213(-22.2), 258(+11.0), 330(-5.7) \mathrm{nm}$.

Methyl diorcinol-4-carboxylate (12): a white solid; UV (MeOH) $\lambda_{\max }(\log \varepsilon) 224$ (3.42), 262 (2.95), 200 (1.36), 301 (1.23) nm; IR (KBr) $v_{\max } 3401,2954,1656,1598,1454,1322,1262,1207,1161,1104,1031,998$, 952, 843, $677 \mathrm{~cm}^{-1} ;{ }^{1} \mathrm{H}$ and ${ }^{13} \mathrm{C}$ NMR (see Table 2); ESI-MS $\mathrm{m} / z 311.1[\mathrm{M}+\mathrm{Na}]^{+}$.

Methyl 3,3-di(O-methyl) diorcinol-4-carboxylate (12a): a white solid; UV (MeOH) $\lambda_{\max }(\log \varepsilon) 222$ (3.34), 228 (3.32), 279 (1.49) nm; IR (KBr) $v_{\max }$ 3440, 2950, 1731, 1587, 1463, 1324, 1268, 1193, 1158, 1093, 1064, 1028, 996, 935, $836 \mathrm{~cm}^{-1} ;{ }^{1} \mathrm{H}$ and ${ }^{13} \mathrm{C}$ NMR (see Table 2); HRESIMS $\mathrm{m} / z 317.1392[\mathrm{M}+\mathrm{H}]^{+}$ (calculated for $\mathrm{C}_{18} \mathrm{H}_{21} \mathrm{O}_{5}, 317.1384$ ) (Supplementary Figure S24).

\subsection{Crystallographic Data for Racemic 2}

Racemic 2 was obtained as a light-yellow monoclinic crystal with molecular formula $\mathrm{C}_{11} \mathrm{H}_{17} \mathrm{O}_{2} \mathrm{~N}_{3}$ from $\mathrm{CH}_{3} \mathrm{CH}_{2} \mathrm{OH}$ and $\mathrm{CH}_{2} \mathrm{Cl}_{2}$. Space group P-1, $a=9.8007$ (9) $\AA, b=10.4560(12) \AA, c=12.9125(14) \AA$, $\alpha=122.466(3)^{\circ}, \beta=97.4200(10)^{\circ}, \gamma=106.988(2)^{\circ}, \mathrm{V}=1125.2(2) \AA 3, Z=2, D_{\text {calcd }}=1.259 \mathrm{mg} / \mathrm{m}^{3}$, $\mu=0.089 \mathrm{~mm}^{-1}, F(000)=454$, crystal size $0.34 \times 0.21 \times 0.13 \mathrm{~mm}, \mathrm{~T}=298(2) \mathrm{K}, 2.27^{\circ} \leq 2 \theta \leq 25.02^{\circ}$, 5737 reflections collected, 3915 unique $(R($ int $)=0.0364)$. Final $R$ indices $R^{1}=0.0310, w R^{2}=0.0748$ based on 3915 reflections with $I>2$ sigma $(I)$ (refinement on $\mathrm{F}^{2}$ ), 316 parameters, 0 restraint. Crystallographic data (excluding structure factors) for structure $( \pm)-2$ in this dissertation have been deposited in the Cambridge Crystallographic Data Centre as supplementary publication number CCDC 1837585 (fax, +44-(0)-1223-336033; e-mail, deposit@ccdc.cam.ac.uk). 


\subsection{ECD Calculation Assays}

The calculations were performed by using the density functional theory (DFT) using Gaussian 03. The preliminary conformational distributions search was performed by HyperChem 7.5 software. All ground-state geometries were optimized at the B3LYP/6-31G(d) level. Conformers within a $2 \mathrm{kcal} / \mathrm{mol}$ energy threshold from the global minimum were selected to calculate the electronic transitions. The overall theoretical ECD spectra were obtained according to the Boltzmann weighting of each conformers. Solvent effects of methanol solution were evaluated at the same DFT level by using the SCRF/PCM method.

\subsection{Methylation of $\mathbf{1 2}$}

To a solution of $12(10 \mathrm{mg})$ in DMF $(1 \mathrm{~mL})$ were added $\mathrm{K}_{2} \mathrm{CO}_{3}(20 \mathrm{mg})$ and $\mathrm{MeI}(0.03 \mathrm{~mL})$, and

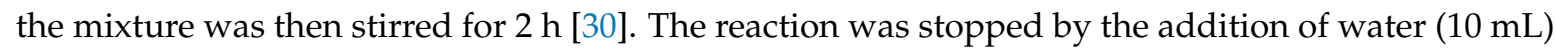
and extracted three times with EtOAc $(3 \times 20 \mathrm{~mL})$, then EtOAc solutions were concentrated under reduced pressure. The mixture was purified by semi-HPLC $\left(80: 20 \mathrm{MeOH} / \mathrm{H}_{2} \mathrm{O}, 4 \mathrm{~mL} / \mathrm{min}\right)$ to give dimethylether derivative $12 \mathrm{a}\left(7.4 \mathrm{mg}, t_{\mathrm{R}} 7.8 \mathrm{~min}\right)$.

\subsection{Antimicrobial Assays}

The MICs of the compounds were tested using the broth microdilution method [31,32]. The pathogenic bacteria included B. subtilis ATCC6051, S. aureus ATCC6538, S. aureus ATCC25923, P. aeruginosa ATCC10145, E. aerogenes, and E. coli ATCC11775 and the pathogenic fungi were C. albicans ATCC10231, and C. glabrata ATCC2001. Ciprofloxacin and ketoconazole were used as positive controls against bacteria and fungi, respectively. All of the microbial strains used in the bioassays are preserved at the Key Laboratory of Chemistry for Natural Products of Guizhou Province, Chinese Academy of Sciences.

\section{9. $\alpha$-Glucosidase Inhibitory Effect Assays}

The inhibitory effects were assayed as described previously [12,13,33]. Absorbance of 96-well plates at $405 \mathrm{~nm}$ was recorded by an Epoch microplate reader (BioTek Instruments, Inc., Winooski, VT, USA). Acarbose was used as a positive control with an $\mathrm{IC}_{50}$ value of $255.3 \mu \mathrm{M}$.

\section{Conclusions}

We identified sixteen compounds from the fermentation of Aspergillus versicolor OUCMDZ-2738 under chemical-epigenetic modification, including a new naturally occurring diketopiperazine derivative (1) and two new compounds, (+)-brevianamide $X((+)-2)$ and (-)-brevianamide $X((-)$-2). We also chirally separated the racemic brevianamides R (3), Q (4), and V (5) into the corresponding optically pure compounds and resolved their absolute configurations for the first time. We clearly determined the structure of the methyl diorcinol-4-carboxylate (12) by preparing 3,3'-dimethylether derivative (12a). Compounds $\mathbf{1 1}$ and $\mathbf{1 2}$ showed selective antibacterial activity against $P$. aeruginosa both with the MIC value of 17.4 and $13.9 \mu \mathrm{M}$, respectively.

Supplementary Materials: The following are available online at http:/ / www.mdpi.com/1660-3397/17/1/6/s1, Figure S1. HRESIMS spectrum of compound 1; Figure S2-S7. NMR spectrum of compound 1; Figure S8. HRESIMS spectrum of compound 2; Figure S9-S14. NMR spectrum of compound 2; Figure S15. The chiral HPLC analysis of compounds 2-5; Figure S16. The chiral HPLC analysis of compounds 7-9; Figure S17. DFT-optimized structures for low-energy conformers of compounds 2-5; Figure S18. Phylogenetic tree mapping for the Aspergillus versicolor OUCMDZ-2738; Figure S19-S23. NMR spectrum of compound 12; Figure S24. HRESIMS spectrum of compound 12a; Figure S25-S29. NMR spectrum of compound 12a; Figure S30. The UPLC-MS Analysis of Fermented Extracts. Figure S31. Retention times of compounds 1-12 in the same elution gradient with original extract fingerprint. The physical properties of the known compounds 3-11.

Author Contributions: W.L. performed the most experiments and prepared the draft of the manuscript. L.W. analyzed the data and revised the manuscript. G.Z. and M.L. performed the chemical calculations. B.W. and Y.X. 
checked the data. K.S. designed the research, checked the data and revised the manuscript. W.Z. designed the research and revised the final version.

Funding: This research was financially supported by the NSFC (Nos. 81803423 \& 41376148), Natural Science Foundation of Zhejiang (No. LQ18D060005), the 100 Leading Talents of Guizhou Province (fund for W.Z.), the science and technology project of Guizhou (No. QKHT Z-2014-4007) and the academician workstation of Guizhou (No. QKH YSZ-2015-4009).

Conflicts of Interest: The authors declare no conflict of interest.

\section{References}

1. Blunt, J.W.; Copp, B.R.; Keyzers, R.A.; Munro, M.H.G.; Prinsep, M.R. Marine natural products. Nat. Prod. Rep. 2017, 34, 235-294. [CrossRef] [PubMed]

2. Blunt, J.W.; Carroll, A.R.; Copp, B.R.; Davis, R.A.; Keyzers, R.A.; Prinsep, M.R. Marine natural products. Nat. Prod. Rep. 2018, 35, 8-53. [CrossRef]

3. Zhu, T.H.; Ma, Y.N.; Wang, W.L.; Chen, Z.B.; Qin, S.D.; Du, Y.Q.; Wang, D.Y.; Zhu, W.M. New marine natural products from the marine-derived fungi other than Penicillium sp. and Aspergillus sp. (1951-2014). Chin. J. Mar. Drugs 2015, 34, 56-108. [CrossRef]

4. Zhuang, Y.; Teng, X.; Wang, Y.; Liu, P.; Li, G.; Zhu, W. New quinazolinone alkaloids within rare amino acid residue from coral-associated fungus, Aspergillus versicolor LCJ-5-4. Org. Lett. 2011, 13, 1130-1133. [CrossRef] [PubMed]

5. Ji, N.Y.; Liu, X.H.; Miao, F.P.; Qiao, M.F. Aspeverin, a new alkaloid from an algicolous strain of Aspergillus versicolor. Org. Lett. 2013, 15, 2327-2329. [CrossRef] [PubMed]

6. Cheng, Z.; Lou, L.; Liu, D.; Li, X.; Proksch, P.; Yin, S.; Lin, W. Versiquinazolines A-K, fumiquinazoline-type alkaloids from the gorgonian-derived fungus Aspergillus versicolor LZD-14-1. J. Nat. Prod. 2016, 79, $2941-2952$. [CrossRef] [PubMed]

7. Shan, W.G.; Wu, Z.Y.; Pang, W.W.; Ma, L.F.; Ying, Y.M.; Zhan, Z.J. $\alpha$-Glucosidase inhibitors from the fungus Aspergillus versicolor 3.05358. Chem. Biodivers. 2015, 12, 1718-1724. [CrossRef]

8. Miao, F.P.; Li, X.D.; Liu, X.H.; Cichewicz, R.H.; Ji, N.Y. Secondary metabolites from an algicolous Aspergillus versicolor strain. Mar. Drugs 2012, 10, 131-139. [CrossRef] [PubMed]

9. Shi, T.; Qi, J.; Shao, C.L.; Zhao, D.L.; Hou, X.M.; Wang, C.Y. Bioactive diphenyl ethers and isocoumarin derivatives from a gorgonian-derived fungus Phoma sp. (TA07-1). Mar. Drugs 2017, 15, 146. [CrossRef] [PubMed]

10. Williams, R.B.; Henrikson, J.C.; Hoover, A.R.; Lee, A.E.; Cichewicz, R.H. Epigenetic remodeling of the fungal secondary metabolome. Org. Biomol. Chem. 2008, 6, 1857-2020. [CrossRef] [PubMed]

11. Cichewicz, R.H. Epigenome manipulation as a pathway to new natural product scaffolds and their congeners. Nat. Prod. Rep. 2010, 27, 11-22. [CrossRef] [PubMed]

12. Sun, K.; Zhu, G.; Hao, J.; Wang, Y.; Zhu, W. Chemical-epigenetic method to enhance the chemodiversity of the marine algicolous fungus, Aspergillus terreus OUCMDZ-2739. Tetrahedron 2018, 74, 83-87. [CrossRef]

13. Sun, K.; Zhu, G.; Hao, J.; Wang, Y.; Zhu, W. Corrigendum to "Chemical-epigenetic method to enhance the chemodiversity of the marine algicolous fungus, Aspergillus terreus OUCMDZ-2739" [Tetrahedron 74 (2018) 83-87]. Tetrahedron 2018, 74, 6465-6466. [CrossRef]

14. Henrikson, J.C.; Hoover, A.R.; Joyner, P.M.; Cichewicz, R.H. A chemical epigenetics approach for engineering the in situ biosynthesis of a cryptic natural product from Aspergillus niger. Org. Biomol. Chem. 2009, 7, 435-438. [CrossRef] [PubMed]

15. Li, G.; Kusari, S.; Golz, C.; Laatsch, H.; Strohmann, C.; Spiteller, M. Epigenetic modulation of endophytic Eupenicillium sp. LG41 by a histone deacetylase inhibitor for production of decalin-containing compounds. J. Nat. Prod. 2017, 80, 983-988. [CrossRef]

16. El-Hawary, S.S.; Sayed, A.M.; Mohammed, R.; Hassan, H.M.; Zaki, M.A.; Rateb, M.E.; Mohammed, T.A.; Amin, E.; Abdelmohsen, U.R. Epigenetic modifiers induce bioactive phenolic metabolites in the marine-derived fungus Penicillium brevicompactum. Mar. Drugs 2018, 16, 253. [CrossRef]

17. Liu, H.; Chen, Z.; Zhu, G.; Wang, L.; Du, Y.; Wang, Y.; Zhu, W. Phenolic polyketides from the marine alga-derived Streptomyces sp. OUCMDZ-3434. Tetrahedron 2017, 73, 5451-5455. [CrossRef] 
18. Du, Y.; Sun, J.; Gong, Q.; Wang, Y.; Fu, P.; Zhu, W. New $\alpha$-pyridones with quorum sensing inhibitory activity from diversity-enhanced extracts of a marine algae-derived Streptomyces sp. J. Agric. Food Chem. 2018, 66, 1807-1812. [CrossRef]

19. Chen, Z.; Hao, J.; Wang, L.; Wang, Y.; Kong, F.; Zhu, W. New $\alpha$-glucosidase inhibitors from marine algae-derived Streptomyces sp. OUCMDZ-3434. Sci. Rep. 2016, 6, 20004. [CrossRef]

20. Li, G.Y.; Li, L.M.; Yang, T.; Chen, X.Z.; Fang, D.M.; Zhang, G.L. Four new alkaloids, brevianamides O-R, from the fungus Aspergillus versicolor. Helv. Chim. Acta. 2010, 93, 2075-2080. [CrossRef]

21. Song, F.; Liu, X.; Guo, H.; Ren, B.; Chen, C.; Andrew, M.P.; Yu, K.; Gao, H.; Wang, Q.; Liu, M.; et al. Brevianamides with antitubercular potential from a marine-derived isolate of Aspergillus versicolor. Org. Lett. 2012, 14, 4770-4773. [CrossRef] [PubMed]

22. Kong, X.; Cai, S.; Zhu, T.; Gu, Q.; Li, D.; Luan, Y. Secondary metabolites of a deep sea derived fungus Aspergillus versicolor CXCTD-06-6a and their bioactivity. J. Ocean Univ. China 2014, 13, 691-695. [CrossRef]

23. Li, G.Y.; Yang, T.; Luo, Y.G.; Chen, X.Z.; Fang, D.M.; Zhang, G.L.; Brevianamide, J. A new indole alkaloid dimer from fungus Aspergillus versicolor. Org. Lett. 2009, 11, 3714-3717. [CrossRef] [PubMed]

24. Zhuravleva, O.I.; Kirichuk, N.N.; Denisenko, V.A.; Dmitrenok, P.S.; Yurchenko, E.A.; Min'ko, E.M.; Ivanets, E.V.; Afiyatullov, S.S. New diorcinol J produced by co-cultivation of marine fungi Aspergillus sulphureus and Isaria felina. Chem. Nat. Compd. 2016, 52, 227-230. [CrossRef]

25. Itabashi, T.; Nozawa, K.; Nakajima, S.; Kawai, K. A new azaphilone, falconensin H., from Emericella falconensis. Chem. Pharm. Bull. 1993, 41, 2040-2041. [CrossRef]

26. Yamamoto, Y.; Nitta, K.; Oohata, Y.; Furukawa, T. Studies on the metabolic products of a strain of Aspergillus fumigatus DH 413. V. A new metabolite produced by ethionine inhibition. Chem. Pharm. Bull. 1972, 20, 931-935. [CrossRef]

27. Gong, D.L.; Wang, X.J.; Xiang, Z.D.; Wang, J.D.; Zhang, H.; Liu, C.X.; Zhang, J.; Xiang, W.S. Diphenyl etheric metabolites from Streptomyces sp. neau50. J. Antibiot. 2011, 64, 465-467. [CrossRef]

28. Smith, S.G.; Goodman, J.M. Assigning stereochemistry to single diastereoisomers by GIAO NMR calculation: The DP4 probability. J. Am. Chem. Soc. 2010, 132, 12946-12959. [CrossRef]

29. Berova, N.; Di Bari, L.; Pescitelli, G. Application of electronic circular dichroism in configurational and conformational analysis of organic compounds. Chem. Soc. Rev. 2007, 36, 914-931. [CrossRef]

30. Chomcheon, P.; Wiyakrutta, S.; Sriubolmas, N.; Ngamrojanavanich, N.; Kengtong, S.; Mahidol, C.; Ruchirawat, S.; Kittakoop, P. Aromatase inhibitory, radical scavenging, and antioxidant activities of depsidones and diaryl ethers from the endophytic fungus Corynespora cassiicola L36. Phytochemistry 2009, 70 , 407-413. [CrossRef]

31. Shen, C.C.; Syu, W.J.; Li, S.Y.; Lin, C.H.; Lee, G.H.; Sun, C.M. Antimicrobial activities of naphthazarins from Arnebia euchroma. J. Nat. Prod. 2002, 65, 1857-1862. [CrossRef] [PubMed]

32. Li, X.D.; Li, X.M.; Xu, G.M.; Zhang, P.; Wang, B.G. Antimicrobial phenolic bisabolanes and related derivatives from Penicillium aculeatum SD-321, a deep sea sediment-derived fungus. J. Nat. Prod. 2015, 78, 844-849. [CrossRef] [PubMed]

33. Wang, C.; Guo, L.; Hao, J.; Wang, L.; Zhu, W. $\alpha$-Glucosidase inhibitors from the marine-derived fungus Aspergillus flavipes HN4-13. J. Nat. Prod. 2016, 79, 2977-2981. [CrossRef] [PubMed]

(C) 2018 by the authors. Licensee MDPI, Basel, Switzerland. This article is an open access article distributed under the terms and conditions of the Creative Commons Attribution (CC BY) license (http://creativecommons.org/licenses/by/4.0/). 